\title{
Time to initiate randomized controlled clinical trials with methadone in cancer patients [version 1; peer review: 2
}

\section{approved]}

\author{
Hans-Joachim Kremer (iD
}

Medical Writing Service, Freiburg, 79117, Germany

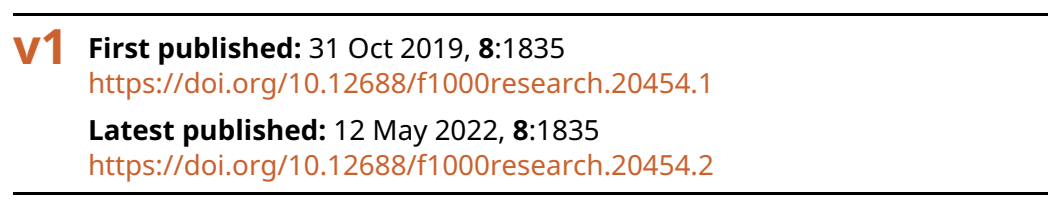

\section{Abstract}

Public media coverage has fueled a demand for methadone as potential cure for cancer itself. Because patients have asked for respective prescriptions, clinical societies issued statements warning against the use of methadone as long as preclinical findings have not been supported by clinical evidence. In fact, not all preclinical data clearly support relevant effects. However, strong epidemiologic data suggest beneficial effects of methadone on cancer. Alternative explanations, namely better safety of methadone or hidden selection bias, seem less likely. This uncertainty can only be resolved by randomized controlled clinical trials. This review discusses all relevant data pertinent to methadone and cancer, uncovers supportive epidemiologic data, and suggests possible study designs.

\section{Keywords}

Methadone, doxorubicin, cancer, randomized controlled clinical trials

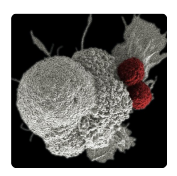

This article is included in the Oncology

gateway.

\section{Open Peer Review \\ Approval Status \\ 1 \\ 2 \\ version 2 \\ (revision) \\ 12 May 2022 \\ version 1 \\ 31 Oct 2019

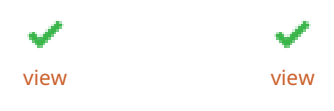 \\ 1. Mary Lynn McPherson, University of \\ Maryland, Baltimore, USA
2. Harald Köfeler (iD), Medical University of
Graz, Graz, Austria \\ Any reports and responses or comments on the article can be found at the end of the article.}


Corresponding author: Hans-Joachim Kremer (hans-joachim.kremer@t-online.de)

Author roles: Kremer HJ: Conceptualization, Formal Analysis, Investigation, Methodology, Project Administration, Resources, Supervision, Validation, Visualization, Writing - Original Draft Preparation, Writing - Review \& Editing

Competing interests: No competing interests were disclosed.

Grant information: The author(s) declared that no grants were involved in supporting this work.

Copyright: ( $) 2019$ Kremer HJ. This is an open access article distributed under the terms of the Creative Commons Attribution License, which permits unrestricted use, distribution, and reproduction in any medium, provided the original work is properly cited.

How to cite this article: Kremer HJ. Time to initiate randomized controlled clinical trials with methadone in cancer patients [version 1; peer review: 2 approved] F1000Research 2019, 8:1835 https://doi.org/10.12688/f1000research.20454.1

First published: 31 Oct 2019, 8:1835 https://doi.org/10.12688/f1000research.20454.1 


\begin{tabular}{ll}
\multicolumn{2}{l}{ List of abbreviations } \\
AIDS & Acquired immunodeficiency syndrome \\
ART & Antiretroviral therapy \\
CI & Confidence interval \\
CNS & Central nervous system \\
HIV & Human immunodeficiency virus \\
HR & Hazard ratio \\
MGMT & O6-methylguanin-DNA-methyltransferase \\
MMT & Methadone maintenance therapy \\
OR & Opioid rotation \\
SD & Standard deviation \\
VA & Veterans Affairs
\end{tabular}

\section{Background}

Since 2017, public media have suggested methadone as a potential cure of cancer. As a result, patients are demanding a prescription of methadone when cancer has been diagnosed or has progressed, perhaps with pain as an excuse. An unrepresentative online survey among German oncologists, conducted in summer 2017 , indicated that $83 \%$ of 473 responding physicians had experience with patients who "frequently or very frequently" asked for methadone therapy ${ }^{1}$. There are indications that an increase in the demand for methadone has spread from Germany to Austria and Switzerland, and beyond ${ }^{2,3}$.

It is certainly not in the interest of medical sciences and not of future patients, if today's patients continue demanding methadone for an unproven therapy. Not surprisingly, several clinical societies have published warning statements on the use of methadone as a cancer therapy ${ }^{4-7}$. While all of these societies called for controlled clinical data, they did not evaluate encouraging data on methadone and did not propose designs for a clinical trial. Sometimes, they warned on use of methadone with questionable arguments on its safety. Whether associated to this skepticism or not, no clinical trial evaluating methadone for cancer has yet been initiated, although 152 and 47 trials with methadone as an intervention, but other uses, have been posted on clinicaltrials.gov and in the EU Clinical Trials register, respectively, since $2013^{8}$. Therefore, this article reviews the all data that could provide a rationale for evaluating methadone as an anticancer agent.

General pharmacological properties of methadone are not discussed here. These properties were discussed in a review proposing methadone as a "tumor theralgesic". However, it did this without thoroughly discussing the clinical and epidemiologic evidence 9 . It should be stressed that methadone is a racemate and should be understood as such unless therwise indicated. The levo- or (-) form is considered to be active at the $\mu$-opioid receptor, the dextro or (+) form is considered inactive there; other opioid receptors appear to be largely unaffected by both forms ${ }^{10}$. In the USA, methadone is licensed for the treatment of moderate to severe pain not responsive to non-narcotic analgesics, for detoxification treatment of opioid addiction, and for maintenance treatment of opioid addiction $^{11}$. In many European countries, methadone is only approved for the treatment of opioid drug addiction ${ }^{12}$. In some European countries, levomethadone is available for the treatment of severe pain and treatment of opioid drug addiction ${ }^{13}$. Dextromethadone has not been approved anywhere, but is currently undergoing a clinical research program major depressive disorder ${ }^{14}$.

\section{Preclinical findings}

Preclinical data, rather than clinical observations, have triggered research on the use of methadone in cancer. Already in the 1980s, studies on neuroblastoma indicated delayed tumor growth after opioids of the morphine-type and their antagonism by naltrexone ${ }^{15-17}$. Similar findings were reported for morphine and naloxone in lung cancer cells, although in concentrations far above the therapeutic range ${ }^{18}$. That group then investigated methadone in human lung cancer cells ${ }^{19}$. Some effects were observed already at concentrations of $1 \mathrm{nM}$ and strong effects at $10 \mathrm{nM} ; 10 \mathrm{nM}$ correspond to about $3 \mathrm{ng} / \mathrm{mL}$, i.e. rather below therapeutic plasma levels (see below). They also found similar effects with dextromethadone alone, which was slightly more active than levomethadone in some cell lines. These data prompted further studies by this group confirming the effects of methadone ${ }^{20-23}$. Apparently, these findings were not challenged by other groups.

Rather high concentrations of methadone, but not morphine, hydromorphone, or naloxone, increased the accumulation of vinblastine in multidrug resistant cells ${ }^{24}$.

Interest in the antineoplastic potential of methadone was revived about 10 years later when a German group around Claudia Friesen took up these data ${ }^{25}$. Her group found that methadone inhibited proliferation of HL-60 myeloid leukemia cells and activated apoptosis pathways. In particular, methadone was able to overcome chemo- and apoptosis resistance, especially but not only resistance to doxorubicin (HL-60 cells were resistant to doxorubicin at a concentration of $100 \mathrm{ng} / \mathrm{mL}$ ). Methadone alone showed some effects at $15 \mu \mathrm{M}(5000 \mathrm{ng} / \mathrm{mL})$ and was fully effective at $30 \mu \mathrm{M}$. Note, however, that peak concentrations of methadone after oral administration in humans were found between 124 to $1255 \mathrm{ng} / \mathrm{mL}$, and steady state levels between 65 to $630 \mathrm{ng} / \mathrm{mL}^{11}$. Hence, the effects in these cell lines might be insufficient for claiming antineoplastic effects of methadone alone under therapeutic conditions.

Then a Spanish group found that methadone was able to induce a necrotic-like cell death in SH-SY5Y cells, i.e. a cell line commonly used in basic research on neuronal functions and cancer $^{26}$. Although this group admitted to having observed these effects in supratherapeutic doses, they concluded that their finding could explain the toxic effects on various cell lines including cancer and leukemia cells. A Canadian group found methadone to induce apoptosis in pediatric acute lymphoblastic leukemia cells ${ }^{27}$. They determined high levels for $\mathrm{IC}_{50}$ for all but only one pro-B-cell leukemia cell line that exhibited an $\mathrm{IC}_{50}$ 
of "only" $9400 \mathrm{ng} / \mathrm{mL}$, i.e. still clearly above the therapeutic range.

In 2008, the German group filed a patent application that claimed, among others things, that methadone $(1000 \mathrm{ng} / \mathrm{mL})$ could enhance the apoptotic effects of doxorubicin $(100 \mathrm{ng} / \mathrm{mL})$ in glioblastoma cells ${ }^{28}$. Corresponding details were published 2013 showing that methadone at a concentration as low as $100 \mathrm{ng} / \mathrm{mL}$ was able to enhance the apoptotic effects of doxorubicin in concentrations between 10 and $60 \mathrm{ng} / \mathrm{mL}$ in acute lymphoblastic leukemia cells ${ }^{29}$. Peak plasma concentrations of doxorubicin average $4100 \mathrm{ng} / \mathrm{mL}$ (SD 220) after a modest $10 \mathrm{mg} / \mathrm{m}^{2}$ dose ${ }^{30}$. Thus, this apoptosis-enhancing combinatorial effect might occur in the therapeutic range of both substances. The authors explained the interaction by increased cellular uptake of doxorubicin by methadone, which in turn might be explained by a down-regulation of cAMP by the opioid ${ }^{29}$. This group then investigated this interaction in glioblastoma cell lines and confirmed previous findings on apoptosis and doxorubicin enhancement ${ }^{31}$. In this setting methadone exhibited significant effects at $1000 \mathrm{ng} / \mathrm{mL}$ or higher.

Thereafter, public interest grew, fueled by public media; the above-mentioned critical statements from oncologic societies were published, and methadone was investigated by other groups. Levomethadone was found to be ineffective in glioblastoma cells; however, data on the racemate were not reported by that group $^{32}$. Instead of doxorubicin they used temozolomide, an alkylating agent that is recommended for glioblastoma, in contrast to doxorubicin, which is unable to cross the blood-brain barrier, and therefore not recommended for glioblastoma ${ }^{30}$. In fact, no controlled clinical trial of doxorubicin in glioma has ever been published. Conversely, it is unclear whether temozolomide as such is useful in vitro, as it is active only after conversion to 5-(3-methyltriazen-1-yl)-imidazole-4-carboxamide (MTIC) $)^{33}$. Another group also found no interaction of methadone and temozolomide in glioblastoma cell lines and methadone being active in only one cell line at a high concentration of $15000 \mathrm{ng} / \mathrm{mL}^{34}$.

While methadone alone was inactive in melanoma cell lines from a biobank, its combination with cisplatin decreased viability in a cell line displaying a high expression of OPRM1, a main receptor for methadone ${ }^{35}$. However, cell lines expressing OPRM1 were rather rare in this biobank of melanoma cells.

A very recent report again denied in vitro interaction between methadone and temozolomide in glioblastoma cells, but reported decreased viability of fibroblasts after $1 \mu \mathrm{M}$ methadone, i.e. about $300 \mathrm{ng} / \mathrm{mL}^{36}$.

A more detailed review on preclinical research findings on antineoplastic effects of methadone was published end of $2018^{3}$.

\section{Epidemiological data}

From the plethora of epidemiologic studies with methadone, those with data on mortality were selected.
Rather normal, non-HIV, non-metastatic patients

A thorough analysis of the Veterans Affairs (VA) database compared mortality after treatment with long-acting morphine and methadone ${ }^{37}$. The aim was to compare the safety as some authors had suggested disadvantages of methadone.

The authors identified patients who had received a new prescription for either methadone or long-acting morphine. The time frame was 2000 through 2007. They analyzed 98,068 patients in the primary analysis cohort. It should be stressed that they specifically excluded patients diagnosed with metastatic cancer and those in palliative care, and patients receiving methadone for opioid addiction (because morphine is not used for this indication and would therefore be an inappropriate control). The analyzed population was composed of patients who mainly used the drugs for a non-cancer pain indication and some who used them for non-metastatic cancer pain; less than 2\% had HIV/AIDS (Table 1).

To control for selection bias, they calculated propensity scores based on several demographic and medical data and split the set into five demographically more homogenous quintiles. The Kaplan-Meier survival function calculated for these quintiles found clearly improved survival (i.e. low hazard ratios, HR, cf. Table 1) in Quintile 1 favoring methadone over long-acting morphine. Quintiles 2 to 4 also indicated an advantage of methadone, but less clearly. The last quintile indicated no difference in survival. The actual survival curves indicated that Quintile 1 was at greatest risk, while Quintiles 4 and 5 were at lowest risks. A closer look at the data including the appendix of this article ${ }^{37}$ suggests that "any malignancy" was the most important dichotomic factor and that age was the most important continuous factor yielding low propensity scores and lower quintile numbers.

To test the robustness of their findings, the authors also analyzed the data after exclusion of patients "with any cancer diagnostic code"; note that this term led to numbers different from those pertinent to "any malignancy". The authors found that the difference in survival in this subcohort "noncancer" was reduced as compared to the primary analysis set (Table 2). These data allow a recalculation of the HR of the alternative subcohort "cancer", which was even more favorable for methadone (Table 2).

Hence, this powerful epidemiologic study indicates:

- Methadone appears to have a survival advantage (HR 0.56) compared with long-acting morphine in patients which are non-metastatic, non-HIV, and non-addicts.

- The advantage is reduced or even abolished in patients without malignancy and in younger patients.

- The advantage is even more pronounced in patients with a malignant history. This holds true overall (subcohort "cancer": HR 0.51) and especially for those with highest prevalence of malignancies (Quintile 1: HR 0.36). 
Table 1. VA study of Krebs et al. 2011: Main data of the propensity quintiles.

\begin{tabular}{|c|c|c|c|c|c|c|c|c|c|c|}
\hline \multirow[t]{2}{*}{ Quintile } & \multicolumn{2}{|c|}{1} & \multicolumn{2}{|c|}{2} & \multicolumn{2}{|c|}{3} & \multicolumn{2}{|c|}{4} & \multicolumn{2}{|c|}{5} \\
\hline & Meth & LA mo & Meth & LA mo & Meth & LA mo & Meth & LA mo & Meth & LA mo \\
\hline$P \cdot Y$ & 947 & 5707 & 2923 & 11775 & 4202 & 11739 & 5869 & 10989 & 8179 & 8268 \\
\hline Ratio Me/Mo & \multicolumn{2}{|c|}{0.166} & \multicolumn{2}{|c|}{0.248} & \multicolumn{2}{|c|}{0.358} & \multicolumn{2}{|c|}{0.534} & \multicolumn{2}{|c|}{0.989} \\
\hline Age (mean, y) & 64 & 64 & 60 & 61 & 58 & 58 & 55 & 55 & 52 & 52 \\
\hline Any malign. (\%) & 43 & 45 & 29 & 30 & 17 & 17 & 10 & 10 & 4 & 4 \\
\hline MI (\%) & 14 & 13 & 13 & 13 & 10 & 10 & 8 & 8 & 6 & 6 \\
\hline $\mathrm{CHF}(\%)$ & 25 & 24 & 21 & 21 & 17 & 17 & 14 & 14 & 10 & 10 \\
\hline HIV/AIDS (\%) & 2 & 2 & 2 & 2 & 1 & 1 & $<1$ & $<1$ & $<1$ & $<1$ \\
\hline Tobacco disorders [\%] & 36 & 34 & 41 & 39 & 44 & 44 & 48 & 48 & 52 & 53 \\
\hline Back pain (\%) & 63 & 59 & 74 & 74 & 81 & 82 & 88 & 89 & 94 & 93 \\
\hline Joint or limb pain (\%) & 79 & 74 & 81 & 82 & 85 & 85 & 88 & 87 & 89 & 90 \\
\hline $\mathrm{HR}$ & \multicolumn{2}{|c|}{0.36} & \multicolumn{2}{|c|}{0.48} & \multicolumn{2}{|c|}{0.50} & \multicolumn{2}{|c|}{0.66} & \multicolumn{2}{|c|}{0.92} \\
\hline
\end{tabular}

P.Y: Person-years ${ }^{37}$.

Ratio Me/Mo indicates the ratio of the P.Y values, methadone by long-acting (LA) morphine per quintile.

The background data were derived from the supplementary appendix ${ }^{37}$. The upper 2 lines (age, any malign.) show two variables that presumably triggered the advantage for methadone over LA morphine concerning survival.

The middle 4 lines (MI, CHF, HIV/AIDS, Tobacco) show otherwise important variables related to survival without obviously relevant differences between the groups. Back pain and joint limb pain are shown as main explanation for the indication and the almost turned Me/Mo ratio in Quintile 5.

An HR below 1 indicates a lower mortality after methadone compared with LA morphine, the lower the better. The HR of 0.36 could be translated e.g. into 100/1000 LA morphine patients died but only 36/1000 methadone patients in the same time interval.

MI: Myocardial infarction. CHF: Congestive heart failure.

Note that the paper did not provide data on the body mass index.

Table 2. VA study of Krebs et al. 2011: HR and 95\% Cl.

\begin{tabular}{|c|c|c|c|c|c|}
\hline & N & Lower margin & HR & Upper margin & Cl width \\
\hline Primary cohort & 98068 & 0.51 & 0.56 & 0.62 & 0.11 \\
\hline Subcohort „non-cancer" & 18013 & 0.69 & 0.78 & 0.87 & 0.18 \\
\hline Subcohort „cancer"a & 80055 & $(0.4375)$ & 0.51 & $(0.5825)$ & 0.145 \\
\hline
\end{tabular}

HR: Hazard ratio of survival estimates. Values below 1 indicate lower mortality after methadone (compared with long-acting morphine) ${ }^{37}$.

${ }^{a} \mathrm{HR}$ and $\mathrm{Cl}$ were not reported in that paper. However, the HR can be estimated from the data given. For the $\mathrm{Cl}$ of this subcohort a $\mathrm{Cl}$ width between the other 2 cohorts was assumed. Note that this is a very conservative strategy given the much higher sample size in the subcohort "cancer".

The authors concluded, conservatively, that they found no evidence of excess all-cause mortality after methadone compared with long-acting morphine. They did not emphasize a possibly protective or beneficial effect with respect to cancer, nor did they provide any rationale for the significant difference in the primary cohort. The vast database makes a chance finding unlikely, although hidden selection bias still cannot be ruled out. The propensity scoring controlled for selection bias to the extent possible, as did other analyses of that group ${ }^{38}$.
Observational study with four treatment cohorts

An earlier retrospective cohort study investigated the safety of newly prescribed methadone, extended-release oxycodone, extended-release morphine, and transdermal fentanyl from a US Medicaid database ${ }^{39}$. This study received less attention than the article discussed above, presumably due to the smaller sample size $(5,684$, divided into four treatment cohorts) and the lack of consistent differences. Abstracted from $p$-values and focused on estimates, this study can be considered in line 
with the VA study discussed above. Among cancer pain patients, mortality rates were lower after methadone than after morphine, while the difference was less pronounced in noncancer pain patients (Table 3), i.e. a pattern similar to that of the VA study (Table 2). The authors also found a trend towards fewer emergency department visits or hospitalizations for methadone compared with morphine (Table 3), although, in all, methadone caused more frequent overdose symptoms. Methadone was also numerically better than oxycodone and fentanyl in cancer pain patients, suggesting unique properties of methadone.

\section{Patients with non-cancer pain}

A retrospective cohort study analyzed data obtained between 1997 and 2009 from the Tennessee Medicaid ${ }^{40}$. The authors included 32,742 sustained-release morphine recipients and 6,014 methadone recipients, and excluded patients with evidence of cancer or HIV infection. They counted only "out-of-hospital mortality given that opioid-related deaths typically occur outside the hospital". This resulted in the rule that "patients in the hospital could not enter the cohort until 30 days after discharge", i.e. early mortality was disregarded. With this dataset they found an HR for mortality of 1.46 (95\% CI: 1.17-1.83), indicating an increased risk of death after methadone. The authors concluded that the increased risk of death observed for users of methadone, even for low doses, supports recommendations that it should not be a drug of first choice for non-cancer pain. The data seem to contradict the VA study regarding the risk in the subcohort "non-cancer". This difference can be explained by the discounting of early deaths in the Tennessee study. Exploratory analyses showed that overdose was the most frequent cause of unbalanced mortality. It should be remembered that methadone is often used in liquid form which facilitates overdose.
Patients with HIV

Several studies and one meta-analysis ${ }^{41}$ have provided comparative mortality data on methadone maintenance therapy (MMT) in HIV patients receiving antiretroviral therapy (ART). The meta-analysis found significant heterogeneity among the studies analyzed. Two Chinese cohort studies were most powerful, one $^{42}$ was included in the above mentioned meta-analysis, the other $^{43}$ is more recent. Both studies indicated that an MMT program is better than withholding methadone; the latter study indicated that stopping opioid use entirely leads to the lowest mortality rates. The proportion of virological suppression showed only a weakly inverse correlation with mortality ${ }^{43}$. Patients with HIV infection are still at risk for the development of AIDS, and often die from various cancers, including Kaposi's sarcoma, non-Hodgkin lymphoma, Burkitt's lymphoma, primary central nervous system lymphoma, and cervical cancer. Interestingly, doxorubicin is first-line treatment for Kaposi's sarcoma and second-line for some forms of leukemia. Although it may be speculative to conclude anticancer efficacy of methadone from these data, they are at least compatible with beneficial effects of methadone alone or in combination with doxorubicin. Further epidemiological research should address a potential interaction.

\section{Miscellaneous}

Literature search for mortality, methadone, and Kaposi sarcoma or lymphoma did not yield meaningful data. The same holds true for searches for Kaposi sarcoma or lymphoma, and vinblastine or doxorubicin, and methadone.

\section{Data from clinical trials}

Cochrane reviews on methadone in noncancer pain $^{44}$ and cancer pain $^{45}$ are available. Both meta-analyses were hampered by low to very low quality of the source studies. The review in

Table 3. Observational comparative 4 cohort study.

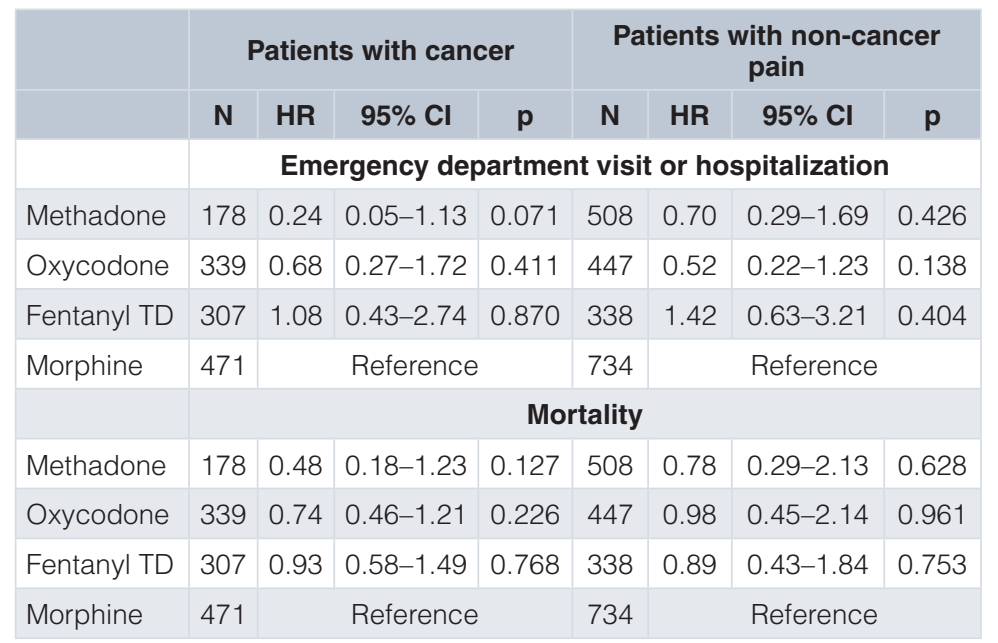

Transcribed from Tables 3, 4, and 5 of reference ${ }^{39}$.

Estimates from Cox Proportional Hazard Models. HR: Hazard Ratio. TD: Transdermal (patch) 
noncancer pain assessed the quantity and quality of evidence as too poor to draw conclusions on efficacy or safety between methadone, placebo, other opioids, or other treatments ${ }^{44}$. The more recent review in cancer pain concluded that methadone has similar analgesic benefits when compared with morphine, is cheaper in many countries, but might be more difficult to handle than morphine or transdermal fentanyl ${ }^{45}$. They found no differences in safety or mortality. A recent overview on several Cochrane reviews confirmed these statements $^{46}$.

\section{Targeted investigations}

The following articles explicitly referred to one of Friesen's $\operatorname{articles}^{25,29,31}$.

\section{Retrospective study in glioma patients}

Friesen and clinicians from Berlin, Germany, published a retrospective study on a rather poorly defined set of glioma patients: In total, 27 patients were exposed to methadone at different stages of therapy; 13 were exposed soon after diagnosis and 12 of these 13 were classified as evaluable for efficacy ${ }^{47}$.

These 12 patients had been diagnosed with a primary glioblastoma multiforme and all initially received surgical therapy, most with gross total resection. After surgery, all received temozolomide and methadone. Of the 12, five were MGMT negative, i.e. at high risk. Of these five, four achieved progression-free survival for 6 months, which according to the authors could be compared with a published survival rate of $40 \%$. The remaining seven patients were MGMT positive, i.e. at low to moderate risk. All seven MGMT-positive patients achieved progression-free survival for 6 months, which compared favorably with a rate of $79 \%$ observed in that centre before methadone was used. These data would be compatible with some beneficial effects, but even negative effects cannot be ruled out due to the small sample size.

The authors also presented safety, progression, and survival data of all 27 patients exposed to methadone. These data cannot be interpreted for efficacy due to heterogeneous baselines and therapies. The authors concluded that methadone can be safely combined with standard glioma chemotherapy. No patient was treated with doxorubicin.

\section{Retrospective opioid-rotation study}

A US group analyzed the data of consecutive supportive care outpatients of a tertiary cancer center ${ }^{48}$. They identified patients who underwent opioid rotation (OR), and defined two cohorts: OR to methadone (76 patients) and OR to any other opioid (88 patients). They found median survival after OR to methadone of 3.75 months (95\% CI: 2.3-6.46) and after OR to other opioids of 2.62 months (95\% CI: 1.74-4.33). The difference was not statistically significant, however, the small sample sizes should be considered. Given the short survival times the difference, if true, appears to be substantial.

The authors also provided data on patients with a follow-up visit. However, these data cannot be interpreted reasonably due to attrition bias, namely early deaths after rotation to other opioids.

\section{Case reports}

Social media are referring to many cases. These are ignored here as long as not published in scientific journals.

There were five isolated case reports recently discussed in an opinion article from an Austrian group that is skeptical on methadone for cancer ${ }^{2}$. Only one of these cases (counted as number 5) may have been relevant, as it was on concomitant use of chemotherapeutics and methadone; unfortunately, the outcome of this case was not reported. The other four cases may be, if any, of little relevance to the efficacy of methadone, as it was administered without concomitant chemotherapy. All these cases, however, illustrate the dilemma for physicians confronted with a patient's last hopes, as methadone was always prescribed on patient's demand.

\section{Discussion of evidence}

The preclinical data suggests that racemic methadone itself can inhibit the growth of human lung cancer cells ${ }^{19}$, increase the uptake of doxorubicin into leukemia cells ${ }^{29}$, and reduce viability of fibroblasts ${ }^{36}$ at concentrations that could be achieved with normal doses. There is little rationale to consider glioma or other CNS cancers as useful indication of methadone or add-on treatment with doxorubicin.

Epidemiological data are encouraging, most of all the VA study $^{37}$. The four-cohort study ${ }^{39}$ numerically supports the findings of the VA study, as well as the opioid rotation study ${ }^{48}$. The study investigating out-of-hospital mortality ${ }^{40}$ should not be considered contradictory due to selective counting of deaths and the focus on noncancer pain. The positive outcomes of HIV studies $^{42,43}$ might be explained by both the beneficial effects on cancer and a diminished use of illicit drugs. However, use of illicit drugs had no relevant quantity in the other studies.

The two targeted investigations were too small, but were also compatible with beneficial effects ${ }^{47,48}$.

All in all, epidemiologic and clinical data consistently indicate that patients treated with methadone had a better prognosis than those treated with morphine, and that this difference was larger the higher the proportion of patients with cancer diagnosis was.

What could alternative explanations be? Is methadone simply safer than long-acting morphine? Other evidence ${ }^{49}$, guidelines ${ }^{50,51}$, and market data $^{52}$ on opioids do currently not support this assumption. Furthermore, there is no pharmacologic or physiologic rationale explaining why such safety advantage could be confined to unselected cancer patients.

Or was there a hidden selection bias? In fact, the VA study ${ }^{37}$ did not control for socioeconomic status. However, it would be counterintuitive to assume that the "cheaper" methadone would be more often prescribed to the "rich" and the "more natural" morphine rather to the "poor".

A reasonable explanation is that methadone yields protective or beneficial effects in cancer. And this effect cannot be explained by an effect of methadone in glioma or other central nervous cancers, as these cancers have too low a prevalence. 


\section{What should be done?}

If methadone is beneficial, whether alone or with doxorubicin, these effects may not be so overwhelming that historically controlled or other cohort studies would be sufficient to demonstrate efficacy. Any uncontrolled distribution of methadone is certainly inappropriate and should not be encouraged. Even prospective registry studies do not appear to be reasonable solutions, as enormous sample sizes would be required given the extreme variability of indications and cancer therapies and the assumed moderate effects. Moreover, prospective registry studies could hamper recruitment into properly designed clinical trials.

As patients will continue demanding methadone for cancer, it is now time to initiate randomized controlled clinical trials with methadone in cancer patients. Doxorubicin could be used in a $2 \times 2$ design or as a factor in the analysis, calling for patients eligible for doxorubicin therapy. Instead, cancer pain should be no selection criterion. The control group could be placebo; however, a reasonable alternative could be watchful waiting for, say, 6 months. This is because most "active" patients and some investigators might correctly guess the true nature of blinded treatment. Moreover, open designs would facilitate treatment of breakthrough pain, maybe with other opioids. Anyhow, the focus should be on opioid-naïve patients.

The dosage of methadone could be based on the paper by Onken et $a l^{47}$. A dose or concentration controlled design could be considered $^{53}$. To investigate opioid-experienced patients, a randomized withdrawal design ${ }^{54}$ might be an option, initially switching all patients to methadone and then withdrawing (or not) it in a blinded manner after, say, 2 weeks. Under such circumstances, it would be unwise to administer any chemotherapy before the end of the withdrawal phase.

Under these prerequisites, methadone appears to be sufficiently safe for initiating a large trial. It should be stressed that it is unclear as to whether methadone would "win" against control. However, almost any outcome would relevantly expand medical knowledge and provide appropriate arguments for answering patients' hopes, whether justified or not.

\section{Conclusions}

- Cancer patients are asking for a methadone therapy, although such therapy is not yet supported by clinical evidence.

- There are nonclinical data supporting its usefulness against certain types of cancer or as enhancer of doxorubicin.

- Strong epidemiologic data support its usefulness for cancer, while alternative explanations rather appear unlikely.

- It is time to initiate randomized controlled clinical trials to test the efficacy of methadone as a therapy for cancer patients.

\section{Data availability}

No data are associated with this article.

\section{Author contribution}

Dr. Hans-Joachim Kremer searched and analyzed literature, and outlined, wrote, and edited the whole manuscript.

\section{Author endorsement}

Wolfgang Bessler confirms that the author has an appropriate level of expertise to conduct this research, and confirms that the submission is of an acceptable scientific standard. Wolfgang Bessler declares they have no competing interests. Affiliation: Institute of Molecular Medicine and Cell Research, University of Freiburg, Freiburg im Breisgau, Germany

\section{Acknowledgement}

I thank Dr. Herbert Sindermann for thorough review and fruitful discussions.
1. German Society for Hematological and Medicinal Oncology: Results of the online survey "Methadon in der Krebstherapie". (in German). Reference Source

2. Kreye G, Masel EK, Hackner K, et al:: Methadone as anticancer treatment: hype, hope, or hazard? : A series of case reports and a short review of the current literature and recommendations of the societies. Wien Med Wochenschr. 2018; 168(7-8): 159-167.

PubMed Abstract | Publisher Full Text

3. Theile D, Mikus G: Methadone against cancer: Lost in translation. Int $J$ Cancer 2018: 143(8): 1840-1848.

PubMed Abstract | Publisher Full Text

4. German Society for Neurology. 2015; Accessed 28 October 2019. Reference Source

5. Hofbauer H, Schenk M, Kieselbach K, et al:: [Use of methadone for support of oncological treatment? : Statement of the working group on tumor pain of the German Pain Society]. Schmerz. 2017; 31(1): 2-4

PubMed Abstract | Publisher Full Text
6. German Cancer Society. 2017; Accessed 28 October 2019 Reference Source

7. Austrian Society for Hematology and Medicinal Oncology. 2017; Accessed 28 October 2019. Reference Source

8. Search at www.clinicaltrials.gov: and separate https://www.clinicaltrialsregister. eu/ctr-search/ on "methadone" as intervention; posted after 1 January 2013 for clinicaltrials.gov; no time restriction applied for the EU register. Lastly searched on 28 October 2019.

9. Michalska M, Katzenwadel A, Wolf P: Methadone as a "Tumor Theralgesic" against Cancer. Front Pharmacol 2017: 8: 733 . PubMed Abstract | Publisher Full Text | Free Full Text

10. Wikipedia: English. Methadone. Accessed August 2019.

11. Drugs@FDA: FDA Approved Drug Products: Methadone. Accessed August 2019. Reference Source 
12. Electronic Medicines Compendium: Methadone $1 \mathrm{mg} / \mathrm{ml}$ oral solution. Accessed August 2019

Reference Source

13. L-Polamidon ${ }^{\circledast}$ Tropfen. Accessed August 2019.

Reference Source

14. Relmada Inc. Accessed August 2019.

Reference Source

15. Zagon IS, McLaughlin PJ: Heroin prolongs survival time and retards tumor growth in mice with neuroblastoma. Brain Res Bull. 1981; 7(1): 25-32. PubMed Abstract | Publisher Full Text

16. Zagon IS, McLaughlin PJ: Naltrexone modulates tumor response in mice with neuroblastoma. Science. 1983; 221(4611): 671-3. PubMed Abstract | Publisher Full Text

17. Zagon IS, McLaughlin PJ: Duration of opiate receptor blockade determines tumorigenic response in mice with neuroblastoma: a role for endogenous opioid systems in cancer. Life Sci. 1984; 35(4): 409-16. PubMed Abstract | Publisher Full Text

18. Maneckjee R, Minna JD: Opioid and nicotine receptors affect growth regulation of human lung cancer cell lines. Proc Natl Acad SciU S A. 1990; 87(9): 3294-8. PubMed Abstract | Free Full Text

19. Maneckjee R, Minna JD: Nonconventional opioid binding sites mediate growth inhibitory effects of methadone on human lung cancer cells. Proc Natl $\mathrm{Acad} \mathrm{SCl}$ US A. 1992; 89(4): 1169-73.

PubMed Abstract | Publisher Full Text | Free Full Text

20. Maneckjee R, Minna JD: Biologically active MK-801 and SKF-10,047 binding sites distinct from those in rat brain are expressed on human lung cancer cells. Mol Biol Cell. 1992; 3(6): 613-9.

PubMed Abstract | Publisher Full Text | Free Full Text

21. Maneckjee R, Minna JD: Opioids induce while nicotine suppresses apoptosis in human lung cancer cells. Cell Growth Differ. 1994; 5(10): 1033-40. PubMed Abstract

22. Maneckjee R, Minna JD: Characterization of methadone receptor subtypes present in human brain and lung tissues. Life Sci. 1997; 61(22): PL 333-8. PubMed Abstract | Publisher Full Text

23. Heusch WL, Maneckjee R: Effects of bombesin on methadone-induced apoptosis of human lung cancer cells. Cancer Lett. 1999; 136(2): 177-85. PubMed Abstract | Publisher Full Text

24. Callaghan R, Riordan JR: Synthetic and natural opiates interact with Pglycoprotein in multidrug-resistant cells. J Biol Chem. 1993; 268(21): 16059-64. PubMed Abstract

25. Friesen C, Roscher M, Alt A, et al.: Methadone, commonly used as maintenance medication for outpatient treatment of opioid dependence, kills leukemia cells and overcomes chemoresistance. Cancer Res. 2008; 68(15): 6059-64. PubMed Abstract | Publisher Full Text

26. Perez-Alvarez S, Cuenca-Lopez MD, de Mera RM, et al:: Methadone induces necrotic-like cell death in SH-SY5Y cells by an impairment of mitochondrial ATP synthesis. Biochim Biophys Acta. 2010; 1802(11): 1036-47. PubMed Abstract | Publisher Full Text

27. Singh A, Jayanthan A, Farran A, et al:: Induction of apoptosis in pediatric acute lymphoblastic leukemia (ALL) cells by the therapeutic opioid methadone and effective synergy with Bcl-2 inhibition. Leuk Res. 2011; 35(12): 1649-57. PubMed Abstract | Publisher Full Text

28. Millner E, Friesen C, Alt A: Use of opioids or opioid mimetics for the treatment of resistant cancer patients. EP 2149372 A1. Date of filing: 31 July 2008. Reference Source

29. Friesen C, Roscher M, Hormann I, et al.: Cell death sensitization of leukemia cells by opioid receptor activation. Oncotarget. 2013; 4(5): 677-90. PubMed Abstract | Publisher Full Text | Free Full Text

30. Drugs @ FDA: FDA Approved Drug Products: Doxorubicin hydrochloride of injection. Checked in August 2019

31. Friesen $\mathrm{C}$, Hormann I, Roscher M, et al:: Opioid receptor activation triggering downregulation of cAMP improves effectiveness of anti-cancer drugs in treatment of glioblastoma. Cell Cycle. 2014; 13(10): 1560-70. PubMed Abstract | Publisher Full Text | Free Full Text

32. Latzer $\mathrm{P}, \mathrm{Kessler} \mathrm{T}, \mathrm{Sahm} \mathrm{F}$, et al.: Methadone does not increase toxicity of temozolomide in glioblastoma cells. Poster 33 Deutscher Krebskongress, 21-24. Februar 2018, Berlin; Oncol Res Treat. 2018; 41(suppl 1): 1-221.

33. Temodar ${ }^{\circledR}:$ Prescribing Information. Accessed 2018-12-31. Reference Source

34. Brawanski K, Brockhoff G, Hau P, et al:: Efficacy of D,L-methadone in the treatment of glioblastoma in vitro. CNS Oncol. 2018; 7(3): CNS18. PubMed Abstract | Publisher Full Text | Free Full Text

35. Brüggen MC, Mangana J, Irmisch A, et al:: Methadone-Not a magic bullet in melanoma therapy. Exp Dermatol. 2018; 27(6): 694-696. PubMed Abstract | Publisher Full Text

36. Oppermann $\mathrm{H}$, Matusova M, Glasow A, et al:: D,L-Methadone does not improve radio- and chemotherapy in glioblastoma in vitro. Cancer Chemother Pharmacol. 2019; 83(6): 1017-1024.

PubMed Abstract | Publisher Full Text

37. Krebs EE, Becker WC, Zerzan J, et al:: Comparative mortality among Department of Veterans Affairs patients prescribed methadone or long-acting morphine for chronic pain. Pain. 2011; 152(8): 1789-95. PubMed Abstract | Publisher Full Text

38. Chou R, Deyo R, Devine B, et al.: The Effectiveness and Risks of Long-Term Opioid Treatment of Chronic Pain. Evidence Report/Technology Assessment No. 218. AHRQ Publication No. 14-E005-EF. Rockville, MD: Agency for Healthcare Research and Quality; September 2014. www.effectivehealthcare.ahrq.gov/ reports/final.cfm.

Publisher Full Text

39. Hartung DM, Middleton L, Haxby DG, et al:: Rates of adverse events of long-acting opioids in a state Medicaid program. Ann Pharmacother. 2007; 41(6): 921-8. PubMed Abstract | Publisher Full Text

40. Ray WA, Chung CP, Murray KT, et al:: Out-of-hospital mortality among patients receiving methadone for noncancer pain. JAMA Intern Med. 2015; 175(3): 420-7. PubMed Abstract | Publisher Full Text | Free Full Text

41. Low AJ, Mburu G, Welton NJ, et al.: Impact of Opioid Substitution Therapy on Antiretroviral Therapy Outcomes: A Systematic Review and Meta-Analysis. Clin Infect Dis. 2016; 63(8): 1094-1104.

PubMed Abstract | Publisher Full Text | Free Full Text

42. Zhao Y, Shi CX, McGoogan JM, et al:: Methadone maintenance treatment and mortality in HIV-positive people who inject opioids in China. Bull World Health Organ. 2013; 91(2): 93-101.

PubMed Abstract | Publisher Full Text | Free Full Text

43. Zhao $\mathrm{Y}$, Zhang M, Shi CX, et al:: Mortality and virological failure among HIVinfected people who inject drugs on antiretroviral treatment in China: An observational cohort study. Drug Alcohol Depend. 2017; 170: 189-197. PubMed Abstract | Publisher Full Text | Free Full Text

44. Haroutiunian S, McNicol ED, Lipman AG: Methadone for chronic non-cancer pain in adults. Cochrane Database Syst Rev. 2012; 11: CD008025. PubMed Abstract | Publisher Full Text | Free Full Text

45. Nicholson AB, Watson GR, Derry S, et al.: Methadone for cancer pain. Cochrane Database Syst Rev. 2017; 2: CD003971. PubMed Abstract | Publisher Full Text | Free Full Text

46. Els C, Jackson TD, Kunyk D, et al.: Adverse events associated with mediumand long-term use of opioids for chronic non-cancer pain: an overview of Cochrane Reviews. Cochrane Database Syst Rev. 2017; 10: CD012509. PubMed Abstract | Publisher Full Text | Free Full Text

47. Onken J, Friesen C, Vajkoczy P, et al.: Safety and Tolerance of D,L-Methadone in Combination with Chemotherapy in Patients with Glioma. Anticancer Res. 2017 37(3): 1227-1235

PubMed Abstract | Publisher Full Text

48. Reddy A, Schuler US, de la Cruz M, et al:: Overall Survival among Cancer Patients Undergoing Opioid Rotation to Methadone Compared to Other Opioids. J Palliat Med. 2017; 20(6): 656-661.

PubMed Abstract | Publisher Full Text | Free Full Text

49. Lauche R, Klose P, Radbruch L, et al.: [Opioids in chronic noncancer painare opioids different? A systematic review and meta-analysis of efficacy, tolerability and safety in randomized head-to-head comparisons of opioids of at least four week's duration]. Schmerz. 2015; 29(1): 73-84.

PubMed Abstract | Publisher Full Text

50. Agency Medical Director's Group (AMDG): Interagency Guideline on Prescribing Opioids for Pain. $3^{\text {rd }}$ Edition, 2015.

Reference Source

51. German Pain Society: <Recommendations of the S3 Guideline Long-term opioid use in non-tumour-related pain - "LONTS">. AWMF Register No 145/003. Lastly corrected 13 January 2015.

52. Drewes AM, Jensen RD, Nielsen LM, et al:: Differences between opioids: pharmacological, experimental, clinical and economical perspectives. $\mathrm{Br} J \mathrm{Clin}$ Pharmacol. 2013; 75(1): 60-78.

PubMed Abstract | Publisher Full Text | Free Full Text

53. Sanathanan LP, Peck CC: The randomized concentration-controlled trial: an evaluation of its sample size efficiency. Control Clin Trials. 1991; 12(6): 780-94. PubMed Abstract | Publisher Full Text

54. Hale M, Khan A, Kutch M, et al: Once-daily OROS hydromorphone ER compared with placebo in opioid-tolerant patients with chronic low back pain Curr Med Res Opin. 2010; 26(6): 1505-18. PubMed Abstract | Publisher Full Text 


\section{Open Peer Review}

\section{Current Peer Review Status:}

\section{Version 1}

Reviewer Report 10 May 2022

https://doi.org/10.5256/f1000research.22485.r136917

(C) 2022 Köfeler $\mathbf{H}$. This is an open access peer review report distributed under the terms of the Creative Commons Attribution License, which permits unrestricted use, distribution, and reproduction in any medium, provided the original work is properly cited.

\section{Harald Köfeler}

Core Facility Mass Spectrometry, Medical University of Graz, Graz, Austria

The opinion article titled ,Time to initiate randomized controlled clinical trials with methadone in cancer patients' by $\mathrm{HJ}$ Kremer is a timely topic with high relevance in the field of cancer therapy. The existing literature about methadone use in cancer therapy is comprehensively evaluated ranging from preclinical findings to epidemiological studies. While the data are not conclusive at this stage, there is reasonable hope that better study designs could provide conclusive data. In fact, many studies are either too small in size or do not have an appropriate study design to be useful. In this sense, the author provides valuable ideas for the design of future clinical trials judging the use of methadone in cancer therapy. At least the reviewed data at hand as of today are encouraging to further pursue this anti-cancer strategy because if future findings are negative there is not much lost, but if they are positive it could be a significant step forward. In summary, this manuscript could be an incentive for the scientific community to pick up an important topic in cancer therapy, which has so far been severely neglected.

\section{Minor comments:}

Page 2, paragraph 2, line 14: '...all the...' instead of '...the all'.

Page 2, paragraph 3, line 6: '...unless otherwise...'

Is the topic of the opinion article discussed accurately in the context of the current literature?

Yes

\section{Are all factual statements correct and adequately supported by citations?} Yes

Are arguments sufficiently supported by evidence from the published literature? Yes 


\section{Are the conclusions drawn balanced and justified on the basis of the presented arguments? Yes}

Competing Interests: No competing interests were disclosed.

Reviewer Expertise: Biochemistry

I confirm that I have read this submission and believe that I have an appropriate level of expertise to confirm that it is of an acceptable scientific standard.

Author Response 10 May 2022

Hans-Joachim Kremer

Thank you very much for your review and the positive opinion.

Competing Interests: No competing interests were disclosed.

Reviewer Report 10 August 2020

https://doi.org/10.5256/f1000research.22485.r66075

(C) 2020 McPherson $\mathbf{M}$. This is an open access peer review report distributed under the terms of the Creative Commons Attribution License, which permits unrestricted use, distribution, and reproduction in any medium, provided the original work is properly cited.

\section{Mary Lynn McPherson}

University of Maryland, Baltimore, MD, USA

I think this is an excellent paper that offers a substantiated proposal that it is indeed time to initiate a randomized controlled clinical trial in cancer patients to determine if methadone therapy improves outcomes or mortality data. The public has become increasingly well-informed (thank you Dr. Google) and the idea that methadone may improve longevity in cancer is too titillating to ignore. However, the data is often controversial and by no means conclusive. Kremer does an excellent job reviewing what we do know to date on this topic and affirms that we are not in a position to support the uncontrolled distribution of methadone for this purpose. He does, however, suggest the time has come to "initiate randomized controlled clinical trials with methadone in cancer patients."

\section{Additional comments:}

In more detail, Kremer provides the background on how the general public has become aware of the potential for methadone possibly improving outcomes in cancer patients. This has resulted in patients demanding methadone therapy when diagnosed with cancer, regardless of the presence of pain. A chronological history of preclinical findings (predating clinical observations) follows, dating back to the 1980s. Interestingly, high concentrations of methadone (but not other opioids) boosted the effect of vinblastine in multidrug resistant cells. Research groups from Germany, 
Spain, and Canada found that methadone induced apoptosis in cancer cells and was able to overcome chemotherapy resistance.

Survival benefit was explored in several studies. The largest included almost 100,000 patients in the Veterans Affairs system. A hazard ratio of 0.56 was seen for survival benefit with methadonetreated patients vs. long-acting morphine in a cohort with non-metastatic cancer, non-HIV, and non-addicts. Several other studies also showed positive outcomes with methadone, although a retrospective cohort study from a Tennessee Medicaid database showed increased mortality with methadone. Two targeted investigations also showed beneficial effects with methadone, although they were small in size.

Kremer concludes by asking more questions than he answers? Is methadone safer or provides benefits in cancer over other opioids? Going on the assumption that there may be something to the protective or beneficial effects of methadone in certain cancers, and possibly as an enhancer of doxorubicin. I agree with Dr. Kremer that it is "time to initiate randomized controlled clinical trials to test the efficacy of methadone as a therapy for cancer patients."

Is the topic of the opinion article discussed accurately in the context of the current literature?

Yes

Are all factual statements correct and adequately supported by citations? Yes

Are arguments sufficiently supported by evidence from the published literature? Yes

Are the conclusions drawn balanced and justified on the basis of the presented arguments? Yes

Competing Interests: No competing interests were disclosed.

Reviewer Expertise: Palliative care, medication management, opioid conversion calculations, methadone dosing

I confirm that I have read this submission and believe that I have an appropriate level of expertise to confirm that it is of an acceptable scientific standard.

Author Response 10 May 2022

Hans-Joachim Kremer

Thank you very much for your review and the positive opinion.

Competing Interests: No competing interests were disclosed. 
The benefits of publishing with F1000Research:

- Your article is published within days, with no editorial bias

- You can publish traditional articles, null/negative results, case reports, data notes and more

- The peer review process is transparent and collaborative

- Your article is indexed in PubMed after passing peer review

- Dedicated customer support at every stage

For pre-submission enquiries, contact research@f1000.com 